\title{
Here ons wag en wag
}

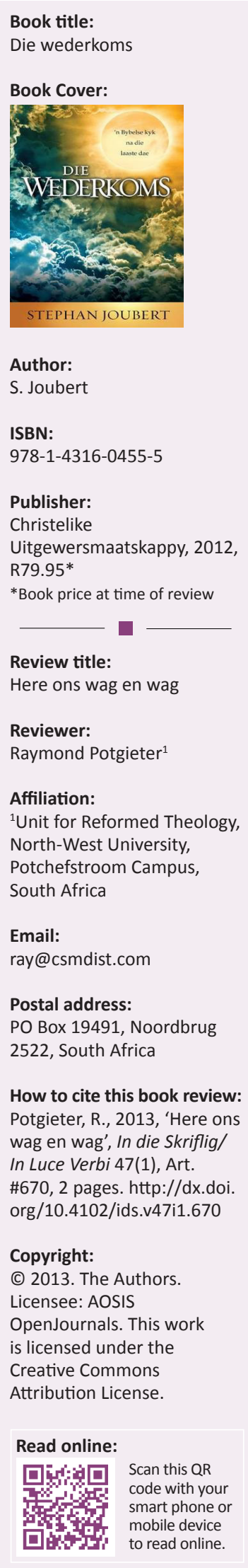

Stephan Joubert, bekende kerkman en akademikus en bekroon met die Andrew Murray-prys, word soms kontroversieel met die 'Opkomende kerk-beweging' geassosieer. Die leser weet dus onmiddellik dat Joubert buite die sogenaamde aanvaarde raamwerk dink. Aan die een kant kan sy denkwyse en skryfstyl verfrissend wees, maar aan die ander kant kan dit ook die oningeligte leser teologies onkant vang.

Joubert se benadering tot die wederkoms word daarop gebaseer dat Jesus Christus nie primêr ontvlugting bied van 'n verskriklike einde nie. Die einde word simbolies deur vuur, pyn en donkerte voorgestel. Jesus is die Saligmaker en Herder van sy skape, en die Bybel is ' $n$ troosboek vir derdemillennium-Christene. Hierdie benadering konfronteer ook die beskouing dat die wêreld se uurglas besig is om uit te loop. Reeds vroeg in die boek (bl. 14) wys hy daarop dat voorspelde eskatalogiese krisisdatums, byvoorbeeld Desember 2012, net soos die ander datums in die verlede, onnodig spoke opjaag. Die vraag wat onstaan, is wat die Christen te doen staan. Joubert is van mening dat dit beslis nie is om oor datums te spekuleer nie, maar om gereed te wees wanneer Jesus kom. Elke Christen kan met die diepe vertroue voortleef dat Jesus nou en tot die einde toe sy kerk in stand sal hou. Joubert fokus ook op die mens se rol tydens die wederkoms. Die mens se rol, so glo hy, kan moontlik die rede wees waarom God die wederkoms kan verhaas of selfs vertraag. Hierdie siening gaan nogtans gepaard met die oproep om as Christen dag na dag vir Jesus se wederkoms gereed te wees.

Op die vraag wat moontlik tot hierdie eindtydspekulasies aanleiding gee, meen Joubert dat die sogenaamde tekens óf histories afwesig was, óf minder prominent gefigureer het, maar in die huidige tydsgleuf met mening na vore kom. Dit dwing nuwe interpretasies af. Die sogenaamde tekens sluit aspekte soos die volgende in: die totstandkoming van Israel as staat, die talle aardbewings, oorloë, kernwapens, plae, prominente leiersfigure wat as die antichris geïdentifiseer word, die Europese Unie, die onthulling van Bybelkodes, die moontlike herbouing van die tempel in Jerusalem, en nog vele meer. Al hierdie dinge is pitkos vir spekulerende teoloë wat die populêre fiksie en teologië van Hagee (bl. 25), Robertson (bl. 28) en nog andere navolg. Die spekulasies word ook deur die sekulêre media uitgebuit om van die kerk en die Christene 'n karikatuur te maak. Joubert se kreet dwarsdeur die boek is egter: 'Terug Bybel toe en daarmee vorentoe.' Dit laat ' $n$ mens amper sinies, maar Joubert lei die leser om die Bybel met doelmatigheid en nugtere denke te benader (hfst. 3).

Joubert se verwysingsraamwerk is hoofsaaklik die bybelse konteks en die mens. Historiese bybelgebeure word vanuit hierdie raamwerk met omsigtigheid na die hede herlei. Die hedendaagse Christen moet dus oplet hoe die Woord in die bybelse verlede vervul is, om die gevolge en implikasies daarvan na die hede toe te herlei. Hierdie benadering lig die Bybel uit as 'n Troosboek (bl. 55). Joubert gebruik 2 Petrus 3 as vertrekpunt vir die begrip rondom die eindtyd en aspekte daarvan soos die konsep rondom tyd of die uitstel van die wederkoms. Vir hom is die presiese datum van die wederkoms van Christus nie vasgestel nie, maar onderhewig aan die aantal plekke wat by die hemelse feesmaal ingeneem moet word (bl. 70-71). Vir die Christen moet die klem wees om die boodskap van God te verkondig en self vir Christus se uitnodiging gereed te wees. Die gebeure van Matteus 24-25 (hfst. 5) word in die lig van die dienskneggestalte van die gelowiges beskou, ongeag die historiese tydperk waarin hulle hul bevind. In hoofstuk 6 hanteer Joubert die bose identiteit van die antichris, die sataniese kenteken van 666 en ander vrae hierrondom. Dit word met omsigtigheid gedoen en met die onderliggende troos dat God se boodskap aan die kerk en die wêreld een van triomf is.

Die mens leef aan albei kante van die graf: met die sekerheid van die kruis aan die een kant en die heerlikheid van die ewige lewe aan die ander kant. Hierdie beligting van die mens lei in die laaste hoofstuk tot die sensitiewe saak van die gelowige se dood en hemelse blyplek. ' $n$ 
Duidelike hantering van die hel en die lewe na die dood tot met die koms van Jesus is egter afwesig in die boek. ' $n$ Sterk punt is dat Joubert nie agter die benadering skuil dat alle eskatologiese sienings slegs simbolies van aard is nie. Dit is die rede waarom hierdie boek ook byval sal vind by diegene wat nie saamstem met alles wat Joubert voorstaan nie.

Die wederkoms kan met vrug deur kleingroepe van die kerk gebruik word. Die prys waarteen dit aangebied word, laat dit selfs toe om 'n paar eksemplare op 'n slag te koop en aan mense te gee wat vrae oor die eindtyd het. Die boek verskaf oorhoofs ' $n$ grondige teologiese en bybelse insig aan diegene wat deur die opwinding van eindtydbespiegelings meegesleur word. Ons betuig ons dank aan Stephan Joubert vir sy versigtige hantering van 'n komplekse tema wat op so 'n manier verwoord is, dat jongmense ook die boek met vrug kan gebruik. 